\title{
Pancreatic and intestinal processing of proglucagon in man
}

\author{
C. Ørskov ${ }^{1}$, J. J.Holst ${ }^{1}$, S. Seier Poulsen ${ }^{2}$ and P. Kirkegaard ${ }^{3}$ \\ ${ }^{1}$ Institute of Medical Physiology C, and \\ ${ }^{2}$ Institute of Anatomy B, the Panum Institute, University of Copenhagen, and \\ ${ }^{3}$ Department of Surgery C, Rigshospitalet, University of Copenhagen, Copenhagen, Denmark
}

\begin{abstract}
Summary. We developed antisera and radioimmunoassays against synthetic replicas of glucagon-like peptide-1 (1-36) and -2 , predicted products of the glucagon precursor, and against glucagon-like peptide-1 (7-36) identical to the sequence of glucagon-like peptide-1, but lacking its first six $\mathrm{N}$ terminal amino acids. With these tools, we studied the localisation and molecular nature of glucagon-like immunoreactivity in human pancreas, small intestine and plasma. By immunohistochemistry glucagon-like peptide-1, and glucagon-like peptide-2 immunoreactivity coexisted with glucagon in pancreatic islet cells and with enteroglucagon in small intestinal enteroglucagon-producing cells. By chromatography of tissue extracts we found that glucagon-like peptide- 1 and glucagon-like peptide-2-immunoreactivities in the human pancreas (307 \pm 51 and $107 \pm 37 \mathrm{pmol} / \mathrm{g}$ tissue) were mainly
\end{abstract}

contained in a large peptide, whereas in the small intestine glucagon-like peptide-1 and glucagon-like peptide-2 immunoreactivities were found in separate smaller molecules ( $49 \pm 21$ and $77 \pm 28 / \mathrm{g}$ tissue). By isocratic high pressure liquid chromatography of the large pancreatic glucagon-like peptide we found that this peptide is heterogeneous. By chromatographic analysis glucagon-like peptide-1 immunoreactivity in fasting plasma was mainly found in a large peptide corresponding to the pancreatic form, while after a meal a smaller molecular form coeluting by gel filtration with glucagon-like peptide-1 predominated.

Key words: Proglucagon, glucagon-like peptide-1, glucagonlike peptide-2, proglucagon 78-107, oxyntomodulin, enteroglucagon, differential processing.
Human proglucagon, as deduced from the nucleotide sequence of the glucagon gene [1, 2], is a peptide of 160 amino acids. Apart from the glucagon sequence and the sequence of the previously known glicentin-related pancreatic peptide (GRPP) it includes an N-terminal 89 amino acid sequence containing two additional glucagon-like sequences. Bell and coworkers predicted that a possible post-translational cleavage of the precursor would occur at the sites of dibasic amino acids, thus resulting in two peptides of 36 and 35 amino acids in addition to the previously known products of proglucagon [1, 2] (Fig. 1). These two glucagon-like sequences, corresponding to amino-acids numbers 72-107 and 126-160 of proglucagon, were designated glucagon-like peptide-1 and -2 (GLP-1 (1-36) and
GLP-2). The GLP-1 (1-36) sequence and glucagon have 14 and GLP-2 and glucagon have 11 amino acids in identical positions.

To investigate whether these glucagon-like peptides are actually formed in the human body, we developed antisera and radioimmunoassays against synthetic replicas of GLP-1 (1-36) and GLP-2 and against GLP-1 (7-36), a sequence identical to GLP-1 (1-36), but lacking the first six N-terminal amino acids of the GLP-1 (1-36) sequence. We found recently that GLP-1 (7-36) is a naturally occurring molecule and the predominating GLP-1 in pig small intestine [3].

We then studied the occurrence and nature of the products of proglucagon in human pancreas, small intestine and plasma by immunohistochemistry and

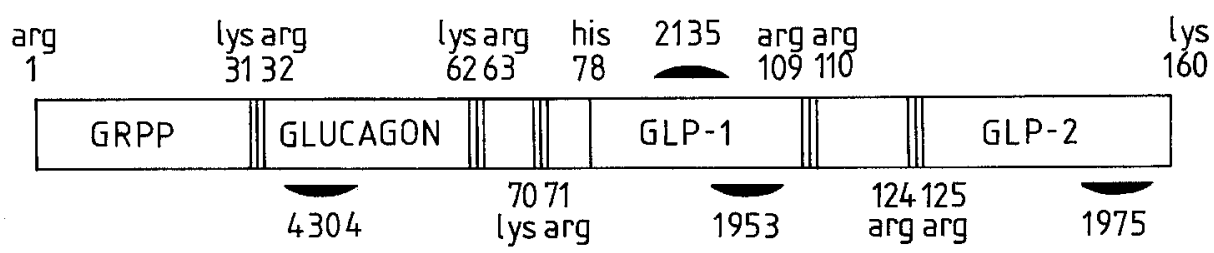

Fig. 1. Human proglucagon is a 160-amino acid peptide precursor [2]. It consists of a 30-amino acid sequence which is homologous to glicentin-related pancreatic peptide (GRPP) (1-30), the glucagon sequence (33-61) and a sequence containing 2 glucagon-like sequences (72-160) ( -159 according to Bell et al. [1]) 
chromatographic analysis of tissue extracts. Furthermore, tissue GLPs were compared with synthetic peptides by high pressure liquid chromatography (HPLC).

\section{Materials and methods}

Human pancreata were obtained from kidney donors during transplantation surgery and pieces of small intestine (whole wall) during surgery on the gastrointestinal tract (both approved by Local Ethical Committee, Rigshospitalet, Copenhagen and The Danish Board of Health).

Peptides for standards and for iodination were: pure, porcine glucagon (Novo Research Institute, Bagsværd, Denmark), synthetic GLP-1 (1-36) amide, (proglucagon 72-108, code no. 7166), synthetic GLP-2 (proglucagon 126-159, code no.7156) and a crude synthetic peptide corresponding to proglucagon 78-107 amide (GLP-1 (7-36) amide). All peptides were obtained from Peninsula (Merseyside, UK). Synthetic GLP-1 (7-36) amide, obtained by custom synthesis was further purified to apparent homogeneity by isocratic reverse phase HPLC in our laboratory prior to use. By amino acid sequencing, it was ascertained that the resulting peptide was GLP-1 (7-36) amide (generously performed by Professor T.W.Schwartz, University of Copenhagen) on an Applied Biosystems gas phase sequencer with HPLC detection of PTH amino acids [3].

GLP-1(1-36)-like immunoreactivity was measured using antiserum code no.1953, labelled and unlabelled peptide as described [4]. Synthetic GLP-1 (1-36) amide was iodinated using a stoichiometric chloramine-T method. GLP-2 immunoreactivity was measured using antiserum code no.1975, and labelled and unlabelled peptide as described in [4]. Synthetic GLP-2, which lacks tyrosine, was iodinated using a chloramine- $T$ method developed for the related peptide secretin [5]. Immunoreactive glucagon was measured using antiserum code no. 4304 which reacts $100 \%$ with all fragments containing the 6-15 residues of glucagon, as described [6]. These include glucagon itself, and enteroglucagons (gut-derived peptides which contains the glucagon sequence. This group includes oxyntomodulin and the pig peptide glicentin) [7]. Neither GLP-1 (1-36), GLP-1 (7-36) nor GLP-2 antisera cross-reacted with any peptide of the secretin/glucagon family (including glucagon, secretin, gastric inhibitory polypeptide, growth hormone-releasing factor (GRF), vasoactive intestinal polypeptide, peptide histidine isoleucineamide, glicentin) or any pancreatic hormones investigated (insulin, somatostatin, pancreatic polypeptide) in concentrations up to $10 \mathrm{nmol} / 1$; neither did the GLP-1 (1-36) and GLP-2 antisera show mutual cross-reactivity. Assay buffer was $0.1 \mathrm{~mol} / 1$ Tris, $\mathrm{pH} 8.5$, containing in addition $2.9 \mathrm{~g} / 1 \mathrm{NaCl}, 2 \mathrm{~g} / 1$ human serum albumin (Behringwerke, Marburg, FRG), thiomersal $0.6 \mathrm{mmol} /$ liter (BDH Chemicals Ldt., Poole, UK) and aprotinin, $66 \mathrm{mg} / 1$ (Trasylol, Bayer, Leverkusen, FRG). The antiserum for the GLP-1 (7-36) amide assay was raised in Danish white rabbits against the synthetic peptide. To enhance immunogenicity, the peptide was coupled to bovine serum albumin with 1-ethyl3(3'-dimethyl-aminopropyl)-carbodiimide (Sigma, St. Louis, Mo, USA), using the same procedure as used for GLP-1 (1-36) and GLP-2 [4]. All antisera were examined for titre (dilution which resulted in approximately 50\% binding of labelled peptide) and avidity as estimated by Scatchard plot analysis [8]. Antiserum code no. 2135 (final dilution 1:20,000) was employed for the radioimmunoassay of GLP-1 (7-36). This antiserum cross-reacted 100\% with synthetic GLP-1, but not with either GLP-2 or glucagon. Antiserum no. 2135, however, reacts more avidly with the large pancreatic peptide than antiserum no. 1953 (Fig.4). GLP-1 (7-36) amide was labelled using a stoichiometric chloramine-T method, described in [4] for labeling of GLP-1 (1-36). The yield of iodination, defined as the fraction of total radioactivity eluted by gel filtration at the position of ${ }^{125}$-I GLP-1 (7-36) amide was $25 \% \pm 10$ in eight experiments. The labelled peptide was stable for at least 2 months. During these 2 months standard curves prepared at least twice a week did not change. Specific activity of tracer was $35 \mathrm{MBq} / \mathrm{nmol}$ (determined as in [4]). For measure- ments of GLP-1 (7-36) amide, $300 \mu$ sample material was preincubated at $4{ }^{\circ} \mathrm{C}$ for $24 \mathrm{~h}$ with $100 \mu \mathrm{l}$ of antiserum, prior to another $24 \mathrm{~h}$ incubation time with labelled peptide. Bound and free moieties were separated with plasma-coated charcoal [4]. Scatchard plots of standard curves obtained under equilibrium conditions (incubation for $48 \mathrm{~h}$ of all components) were curvilinear; the effective equilibrium constant, $K_{\text {eff }}$, was $10^{10} \mathrm{l} / \mathrm{mol}$. The experimental detection limit, calculated by the equation: detection limit $=2$ epsilon $/ K$, where epsilon is the coefficient of variation at standard zero (no addition of unlabelled peptide) and $\mathrm{K}$ the equilibrium constant for association [9], was $8 \mathrm{pmol} / 1$.

\section{Extraction of tissue}

Human pancreatic tissue or pieces of human small intestine were immediately frozen, and subsequently extracted in acid ethanol (method II in [10]). In short, frozen tissue was homogenised in four volumes of acid ethanol and centrifuged. Five volumes of cold diethylether were added to the supernatant, and the aqueous phase was isolated at $-50^{\circ} \mathrm{C}$ and dessicated. The precipitate was dissolved in distilled water containing $8 \mathrm{~mol} / 1$ urea, and subjected to gel filtration (see below).

\section{Chromatography}

Extracts were gel filtered on $50 \times 1000 \mathrm{~mm}$ columns (K 50/100, Pharmacia Fine Chemicals, Uppsala, Sweden) packed with Sephadex G-50 fine grade (Pharmacia) with $0.5 \mathrm{~mol} / 1$ acetic acid, at a flow rate of $60 \mathrm{~mL} / \mathrm{h}$. Effluent fractions were freeze-dried and redissolved in assay buffer prior to assay. The void volume, $\left(V_{0}\right)$ and the available inner volume, $\left(V_{i}\right)$ of the gel bed were determined from the elution position of ${ }^{125} \mathrm{I}$-albumin and ${ }^{22}-\mathrm{NaCl}$ both added to all extracts prior to gel filtration. The coefficient of distribution $\left(\mathrm{K}_{\mathrm{d}}\right)$ was calculated for all peak fractions using the formula $K_{d}=\left(V_{e}-V_{o}\right) / V_{i}$ where $\mathrm{V}_{\mathrm{e}}$ was the elution position of the peak investigated.

\section{High pressure liquid chromatography (HPLC)}

Peak GLP-1 (1-36), GLP-1 (7-36) and GLP-2-immunoreactive fractions of human pancreatic and ileal extracts were subjected to HPLC.

Pancreas: We attempted to separate GLP-1- and GLP-2- immunoreactivity from the $K_{d} 0.33$ peak by gradient and subsequently by isocratic, $57 \%$ ethanol HPLC.

Ileum: The retention times of synthetic GLP-1 (1-36) and GLP-1 (7-36) were compared with the retention time of GLP-1-immunoreactive fractions from extracts of human intestine obtained by gradient and subsequently isocratic, $42 \%$ ethanol HPLC. The retention times of synthetic GLP-2 and ileal GLP-2 were compared by $45-54 \%$ ethanol HPLC. Reverse phase HPLC was performed on $8 \times 250 \mathrm{~mm}$ Nucleosil ${ }^{\circledR}$ C-18 columns employing LKB equipment (LKB, Bromma, Sweden) with ethanol in water (Merck, Darmstadt, FRG) containing in addition $0.1 \%$ trifluoroacetic acid (TFA, Pierce, Rockford, III, USA) for elution. All eluted fractions were evaporated and reconstituted in assay buffer prior to assay.

\section{Plasma studies}

Blood samples were drawn from six healthy volunteers, mean age $35.5 \pm 8$ years, in the fasting state and $2 \mathrm{~h}$ after a mixed meal consisting of $150 \mathrm{~g}$ meat, $200 \mathrm{~g}$ french fries, 0.21 of cream sauce and salad ad libitum. Blood samples were collected in chilled tubes containing $500 \mathrm{KIU}$ aprotinin $/ \mathrm{ml}$ blood and $7.3 \mathrm{mmol} / \mathrm{I}$ EDTA and centrifuged within 0.5 hours. Thirty-millilitre plasma samples were subjected to affinity chromatography as described by Holst [11] using the GLP-1 (1-36) antiserum code no. 1953 ,coupled to CNBr-activated Sepharose 4B according to the manufacturer's instructions (Pharmacia). Bound material was eluted with $5 \%$ formic acid (after a previous 

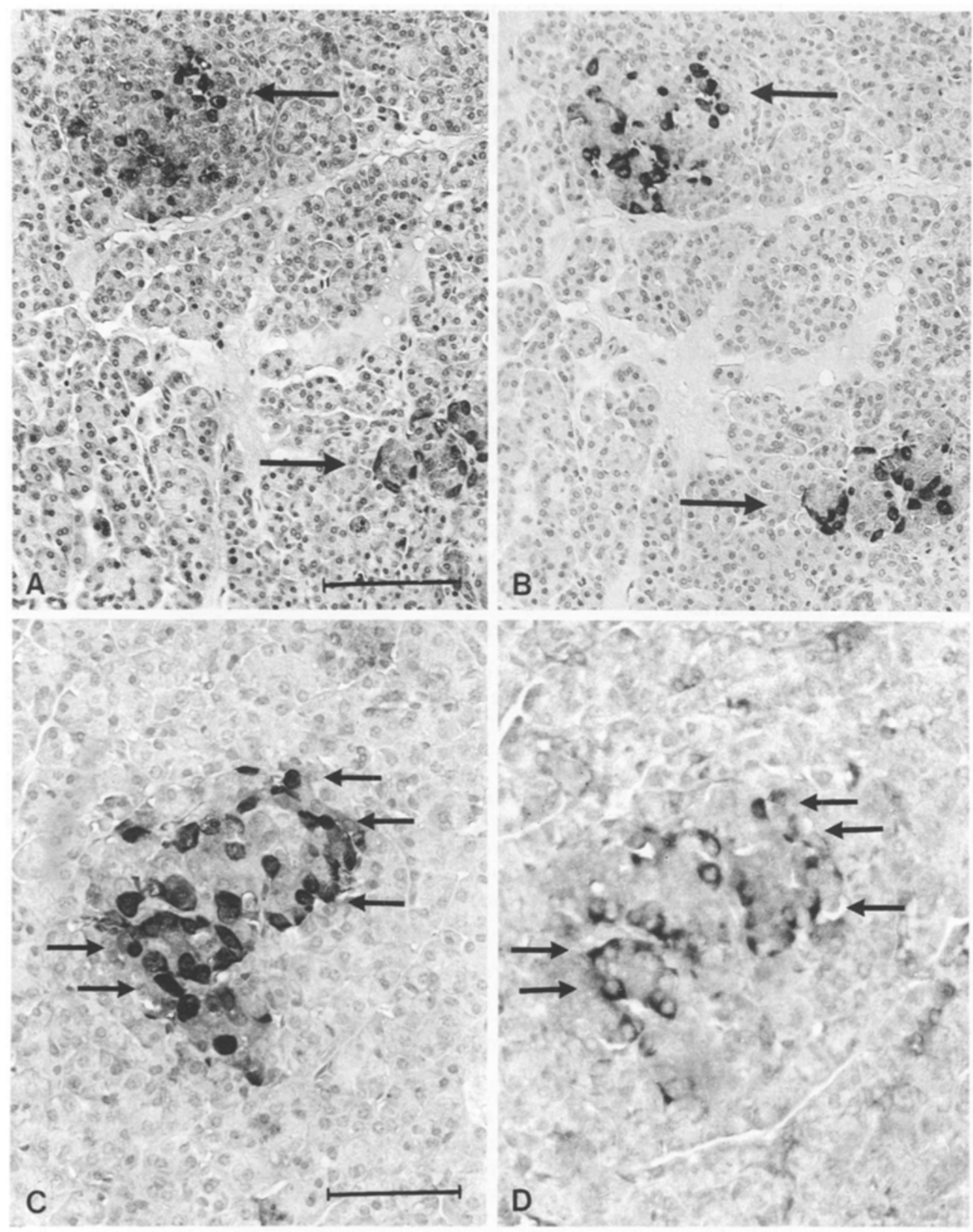

Fig. 2. Colocalisation of glucagon, GLP-1 (1-36) and GLP-2 immunostaining in human pancreatic islet cells. 3-7 $\mu \mathrm{m}$ consecutive sections were stained for glucagon (upper and lower left, antiserum 4304) and either GLP-1 (1-36) (upper right, antiserum 1953) or GLP-2 (lower right, antiserum 1975) by the unlabelled antibody peroxidase antiperoxidase technique. Horizontal bar in upper left corner represents $300 \mu \mathrm{m}$. Horizontal bar in lower left corner represents $150 \mu \mathrm{m}$. Identical cells in adjacent sections are indicated with arrows

wash with $0.5 \mathrm{~mol} / 1 \mathrm{NaCl}, \mathrm{pH} 10$, to remove non-specifically bound material), lyophilised and reconstituted in assay buffer prior to application on gel filtration columns. Gel filtrations were performed on $16 \times 1000 \mathrm{~mm}$ columns (K 16/100, Pharmacia) packed with Sephadex G-50 fine grade (Pharmacia) in assay buffer. A small amount of ${ }^{125}$-I albumin and ${ }^{22}-\mathrm{NaCl}$ was added to all samples prior to gel filtration, for internal calibration.

\section{Immunohistochemistry}

Human pancreatic tissue and tissue from small intestine were fixed by immersion into $4 \%$ icecold paraformaldehyde in $0.1 \mathrm{~mol} / 1$ sodium phosphate at $\mathrm{pH} 7.4$. The tissues were postfixed for $24 \mathrm{~h}$ and transferred to sucrose ( $20 \%$ in $0.1 \mathrm{~mol} / 1$ sodium phosphate, $\mathrm{pH} 7.4$ ). They were then embedded in paraffine, and sections of 3-7 $\mu \mathrm{m}$ cut on sledge microtome (Frieden-Jung, Vienna, Austria). For immunohistochemistry the unlabelled antibody peroxidase-antiperoxidase (PAP) technique was applied as described by Sternberger [12]. Glucagon antiserum code no.4304, GLP-1 (1-36) antiserum code no. 1953, and GLP-2 antiserum code no. 1975 were used. All antisera were diluted $1: 1600$.

\section{Results}

\section{Immunohistochemistry}

Glucagon, GLP-1 (1-36), and GLP-2 immunoreactivities were found in the periphery of clusters of islet cells of human pancreas. On 3-7 $\mu \mathrm{m}$ consecutive sections, GLP-1 (1-36) and glucagon immunoreactivity and GLP-2 and glucagon immunoreactivity were found in the same cells (Fig. 2). In human ileal mucosa glucagon immunoreactivity as well as GLP-1 (1-36), and GLP-2 immunoreactivity were found in open-type endocrine 

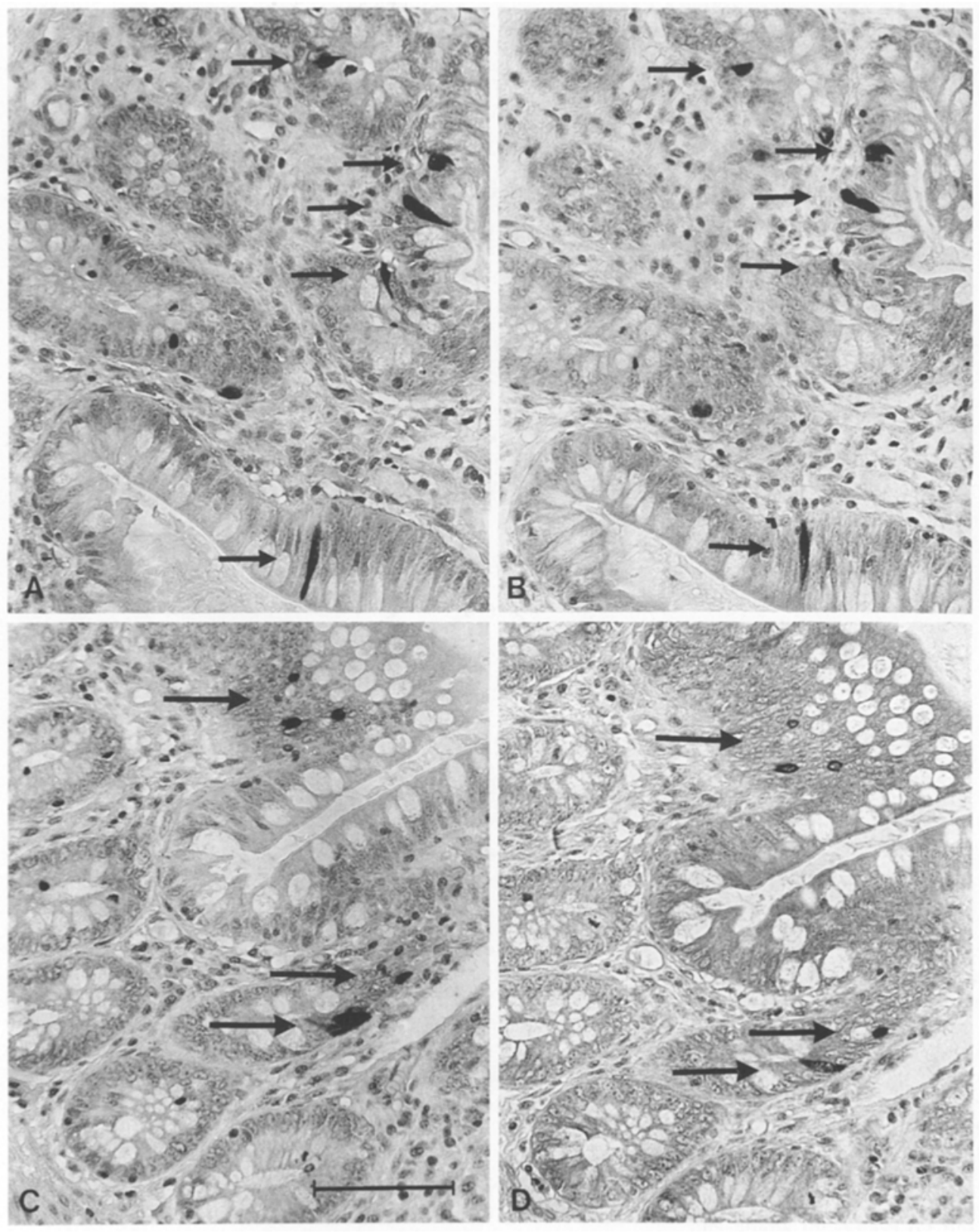

Fig. 3. Colocalisation of enteroglucagon, GLP-1 (1-36) and GLP-2 immunostaining in human enteroglucagon producing cells. $3-7 \mu \mathrm{m}$ consecutive sections were stained for enteroglucagon (upper and lower left, antiserum 4304) and either GLP-1 (1-36) (upper right, antiserum 1953) or GLP-2 (lower right, antiserum 1975) by the unlabelled antibody peroxidase antiperoxidase technique. Horizontal bar in lower left corner represents $150 \mu \mathrm{m}$. Identical cells in adjacent sections are indicated with arrows

cells. On 3-7 $\mu \mathrm{m}$ consecutive sections, glucagon and GLP-1 (1-36), and glucagon and GLP-2 immunoreactivity, respectively, were found in the same cells (Fig.3).

\section{Extracts}

Human pancreatic extracts contained immunoreactive GLP-1 (1-36) and GLP-2 corresponding to $308 \pm 51$ and $107 \pm 37 \mathrm{pmol} / \mathrm{g}$ tissue (wet weight, mean $\pm \mathrm{SEM}$, $n=4)$. Immunoreactive GLP-1 (7-36) content was $235 \pm 67 \mathrm{pmol} / \mathrm{g}$ tissue. Immunoreactive glucagon content, measured with the glucagon 6-15 assay (antibody no. 4304) was $502 \pm 65 \mathrm{pmol} / \mathrm{g}$ tissue. Intestinal extracts contained immunoreactive GLP-1 (1-36) and GLP-2 corresponding to $49 \pm 21$ and $77 \pm 28 \mathrm{pmol} / \mathrm{g}$ tissue (wet weight, mean $\pm \mathrm{SEM}, n=4$ ). The immuno- reactive GLP-1 (7-36) content was $56 \pm 29 \mathrm{pmol} / \mathrm{g}$ tissue. Immunoreactive enteroglucagon as determined with the glucagon 6-15 assay (antiserum 4304) amounted to $46 \pm 13 \mathrm{pmol} / \mathrm{g}$ tissue. By gel filtration of human pancreatic extracts, we found that the majority of GLP-1 (1-36), GLP-1 (7-36) and GLP-2 immunoreactivities coeluted at $K_{d} 0.33$ (Fig. 4). A smaller amount of immunoreactive GLP-1 (1-36) and GLP-1 (7-36) were found at $K_{d} 0.51$, and a smaller amount of immunoreactive GLP-2 was measured at $K_{d} 0.45$. Virtually all glucagon immunoreactivity eluted at $\mathrm{K}_{\mathrm{d}} 0.67$, corresponding to the elution position of the glucagon marker. By isocratic reverse-phase, high pressure liquid chromatography (HPLC) of the GLP-1 (1-36), GLP-1 (7-36) and GLP-2 immunoreactive fractions at $\mathrm{K}_{\mathrm{d}} \mathbf{0 . 3 3}$ with $57 \%$ ethanol in water, the three immunoreactivi- 


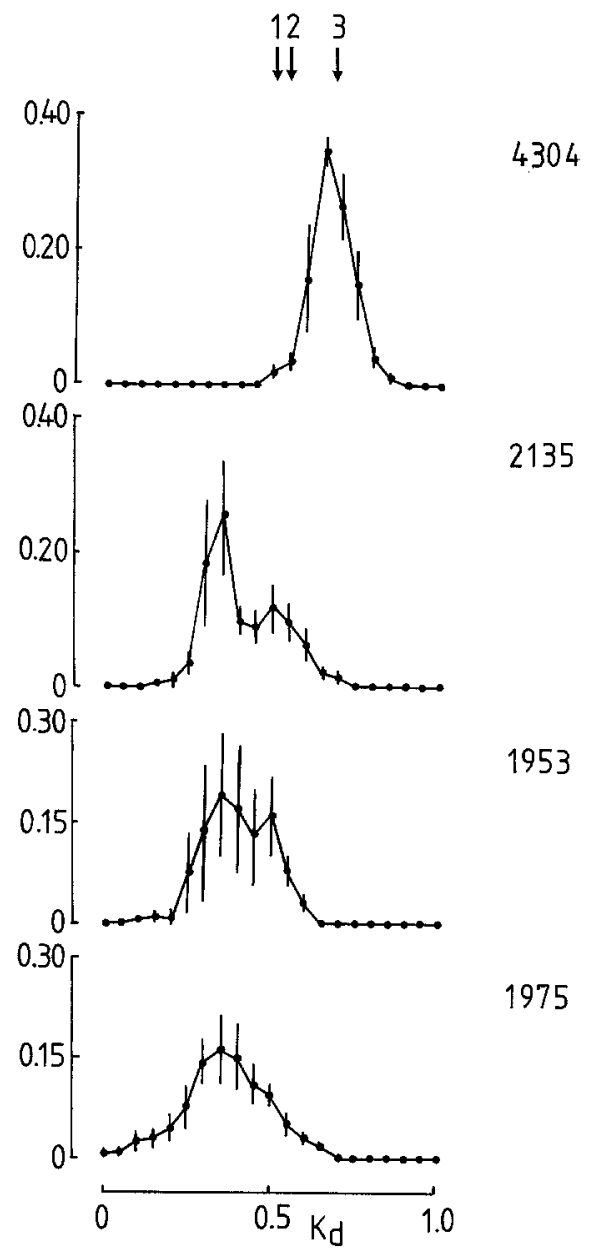

Fig.4. Gel filtration profile of glucagon (as measured with antiserum 4304), GLP-1 (1-36) (as measured with antiserum 1953), GLP-1 (7-36) (as measured with antiserum 2135) and GLP-2 (as measured with antiserum 1975) in extracts of human pancreas $(n=4)$. For each of the gel filtrations the effluent concentrations at each of the $K_{d}$ values indicated by closed circles were read off from the individual elution curves by interpolation if necessary and expressed as percentage of the total amount of immunoreactivity applied to that column; the mean fractional output (mean $\pm S E M$ ) in question was then plotted against $\mathrm{K}_{\mathrm{d}}$. Arrows on top indicate elution position markers ( $1=$ elution position of synthetic GLP-2, $2=$ elution position of synthetic GLP-1 (1-36) and GLP-1 (7-36) amide and $3=$ elution position of glucagon marker)

ties remained unseparated, but eluted in 3 distinct peaks, suggesting that the large GLP-containing peptide investigated was heterogeneous (not shown). After gel filtration of ileal extracts GLP-1 (1-36) and GLP-1. (7-36) immunoreactivity coeluted at $K_{d} 0.57$, corresponding to the elution position of synthetic GLP-1 (1-36) and GLP-1 (7-36), the elution positions of which were indistinguishable by gel filtration (Fig.5). GLP-2 immunoreactivity was found mainly at $K_{d} 0.55$, while the elution position of synthetic GLP-2 was 0.50 . Glucagon-like immunoreactivity as measured with the glucagon 6-15 assay (4304) eluted in two peaks of equal size at $\mathrm{K}_{\mathrm{d}} 0.25$ and 0.60 . The first peak elutes at the elution position of porcine glicentin (MW 8124) [6] and the second peak at the elution position of oxyn-

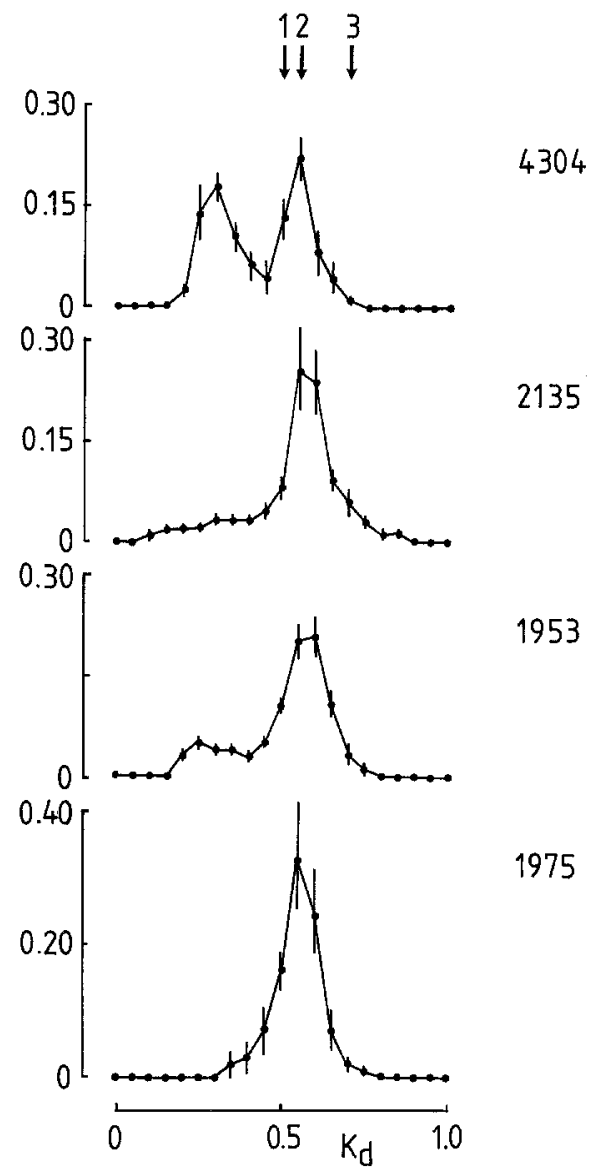

Fig.5. Gel filtration profile of glucagon (antiserum 4304), GLP-1 (1-36) (antiserum 1953), GLP-1 (7-36) (antiserum 2135) and GLP-2 (antiserum 1975) immunoreactivities in extracts of human distal small intestine $(n=4) . K_{d}$ is plotted against mean fractional output (mean $\pm S E M$ ). See legend to Figure 4 for further explanation. Arrows on top indicate elution positions of synthetic GLP-2 [1], GLP-1 (1-36)/GLP-1 (7-36) amide [2] and glucagon [3]

tomodulin, a naturally occurring peptide containing the entire glucagon sequence plus an additional $6 \mathrm{~N}$ terminal amino acids [13]. By isocratic, $42 \%$ ethanol HPLC of synthetic GLP-1 (1-36), synthetic GLP-1 (7-36) amide and peak GLP-1 (1-36) and GLP-1 (7-36) immunoreactivite fractions from ileal extracts, we found the following retention times [Fig. 6]: synthetic GLP-1 (1-36): 18 min, synthetic GLP-1 (7-36) amide: $17 \mathrm{~min}$ and the ileal GLP-1: $10 \mathrm{~min}$.

After gel filtration of human plasma, drawn in the fasting state $(n=6)$, the largest part of GLP-1 (1-36) immunoreactivity was found at $K_{d} 0.20-0.25$. A smaller amount of immunoreactivity was found at $\mathrm{K}_{\mathrm{d}} 0.55$, corresponding to the elution position of synthetic GLP-1 (1-36)/synthetic GLP-1 (7-36). Gel filtration of plasma, drawn $2 \mathrm{~h}$ after a mixed meal, however, showed that the largest amount of GLP-1 (1-36) immunoreactivity was found at $K_{d} 0.60$, corresponding to elution position of synthetic GLP-1 (1-36)/GLP-1 (7-36), while a smaller proportion was found at $K_{d}$ 


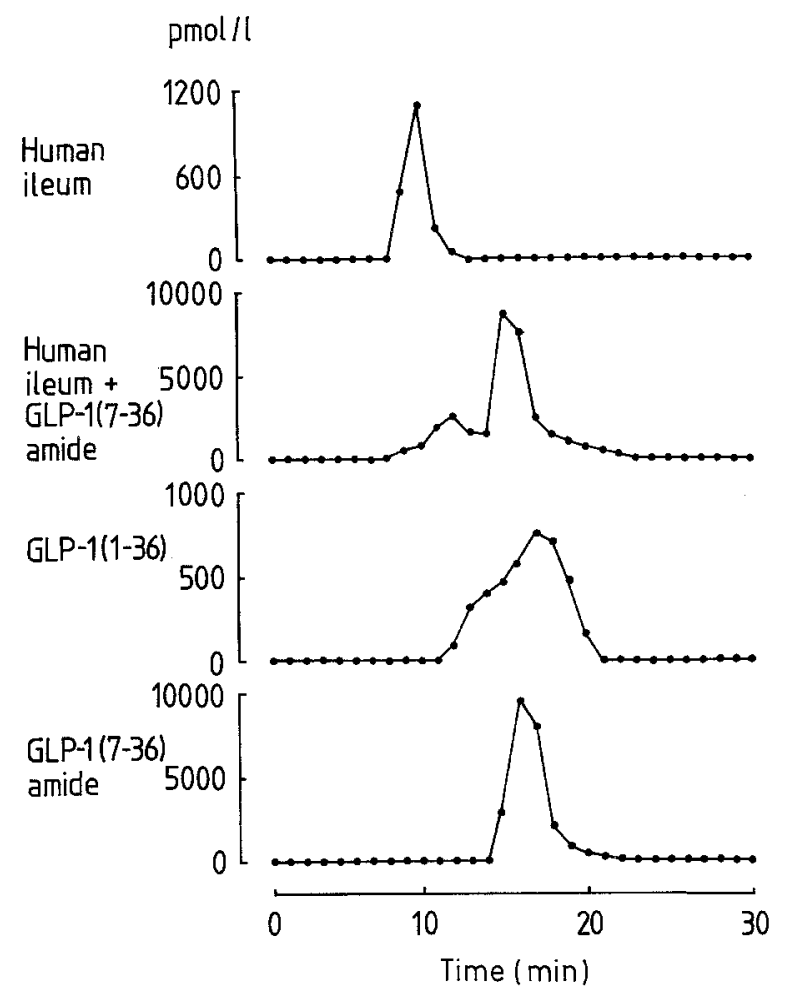

Fig.6. Isocratic $42 \%$ ethanol high pressure liquid chromatography of immunoreactive ileal GLP-1 (upper panel), immunoreactive ileal GLP-1 and synthetic GLP-1 (7-36) amide (second panel), synthetic GLP-1 (1-36) amide (third panel) and synthetic GLP-1 (7-36) amide (lower panel). The concentrations of peptides are plotted against time. Results of 4 consecutive experiments with the same column and reagents

0.20-0.25 (Fig. 7). A similar analysis for plasma GLP-2 immunoreactivity was technically unsuccessful.

\section{Discussion}

This study shows that GLP-1 (1-36) and GLP-2 immunoreactivities are colocalised with glucagon in the glucagon-producing cells of the human pancreas, and with enteroglucagon in the enteroglucagon-producing cells of the human, distal small intestine. Similar findings were reported by Varndell et al. [14]. By gel filtration of pancreatic and ileal tissue extracts, we found that post-translational cleavage of the common prohormone [20], proglucagon, is different in the two tissues. The pancreas produces, apart from glucagon, a large peptide that contains both of the 2 glucagon-like immunoreactivities. The exact size of this peptide is not known, but our results obtained by isocratic HPLC suggest that it is a large heterogenous peptide. We have previously found a similar, large peptide in the pig pancreas [15], but the molecular size of the human pancreatic GLP as judged by the elution position upon gel filtration, is somewhat smaller than the pig pancreatic GLP $\left(\mathrm{K}_{\mathrm{d}} 0.33\right.$ versus $\mathrm{K}_{\mathrm{d}} 0.22$ [15]). Patzelt [16] isolated a large proglucagon fragment from rat pancreas, the
Fractional

output
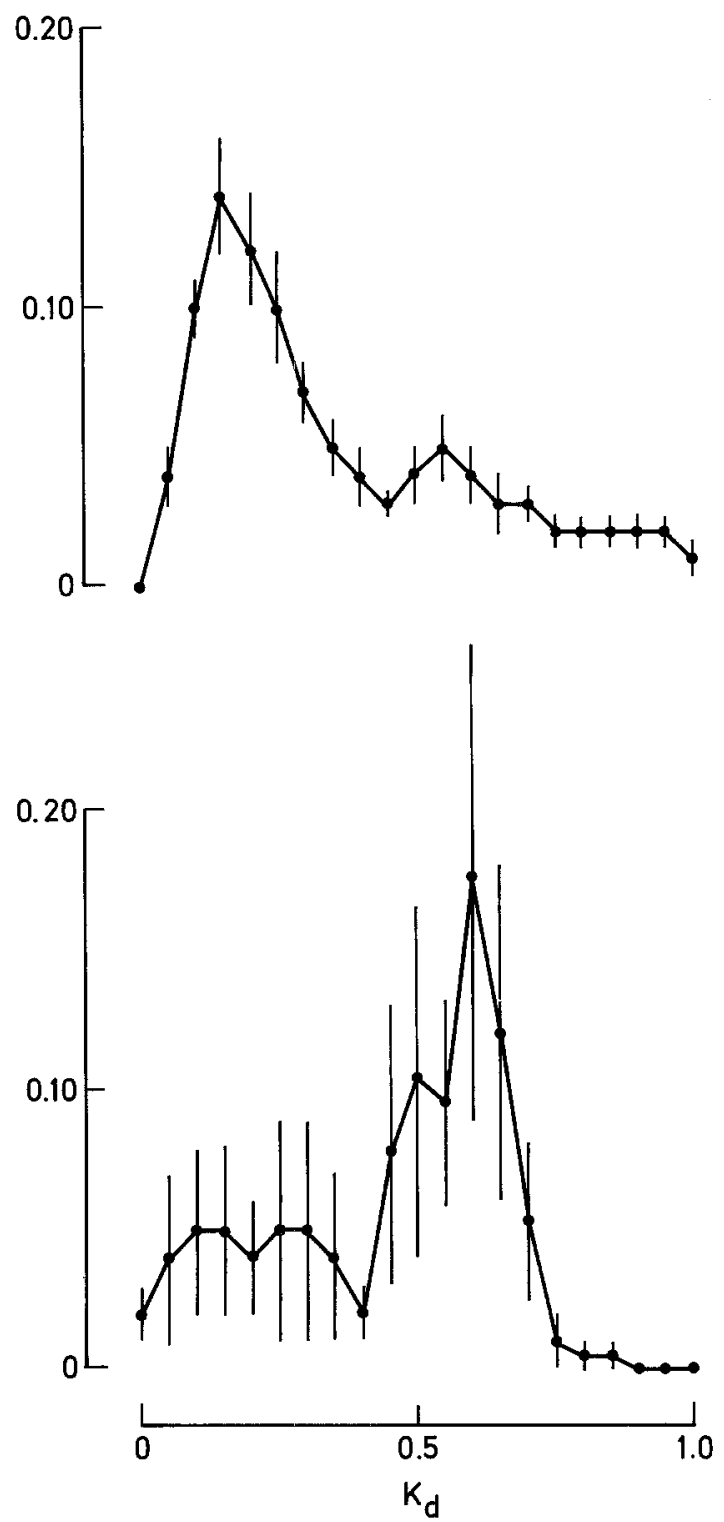

Fig.7. Gel filtration profile of GLP-1-like immunoreactivity (as measured with antiserum no. 1953) in human plasma in the fasting state (top) and in plasma $120 \mathrm{~min}$ after a mixed meal (bottom), $(n=6) . \mathrm{K}_{\mathrm{d}}$ is plotted against mean fractional output (mean $\pm \mathrm{SEM}$ ). See legend to Figure 4 for further explanation. GLP-1 immunoreactivity in plasma in the fasting state was $107 \pm 7 \mathrm{pmol} / 1$, and in plasma after a mixed meal $151 \pm 14 \mathrm{pmol} / \mathrm{l}($ mean $\pm \mathrm{SEM})$

amino acid composition of which was consistent with the presence of the two glucagon-like sequences. We found that the molar ratio between GLP-1 (1-36), GLP-1 (7-36), GLP-2 and glucagon from the human pancreas was close to the expected $1: 1$. Uttenthal et al. [15] reported a molar ratio between glucagon and GLP-1 in the human pancreas of $48: 1$. The antiserum employed, however, was raised against a fragment of GLP-1 (GLP-1, 1-19) which may explain a lower cross-reactivity with natural GLP-1 immunoreactive molecules. In a later work from the same group 
(George et al. [18]) the molar ratio in the pancreas between GLP-1 and GLP-2 were 1:1, but no data on the ratio between glucagon and the two glucagon-like peptides were presented. In the pig pancreas, we earlier found that the molar ratio between GLP-1 and GLP-2 immunoreactivity was $28: 1$ [15]. This discrepancy is probably due to sequential differences between human and pig GLP-2 [19], recently discovered in our laboratory. As estimated by gel filtration we found that the human ileum produces a large molecular weight enteroglucagon (corresponding in size with porcine glicentin), oxyntomodulin and 2 smaller glucagon-like peptides corresponding in size with the synthetic glucagon-like peptides. It was not possible by gel filtration to distinguish between synthetic GLP-1 (1-36) and GLP-1 (7-36). By comparison of synthetic GLP-1 (1-36), GLP-1 (7-36) and ileal immunoreactive GLP-1 by isocratic HPLC however, the ileal GLP-1 immunoreactive material eluted well separated from both synthetic GLP-1 (1-36) and synthetic GLP-1 (7-36) amide, which must mean that the naturally occurring GLP-1 immunoreactive substance differs from both synthetic peptides, although being of a comparable molecular size. The elucidation of the nature of the difference must await amino acid sequence analysis of the naturally occurring peptide; however the difference may be due to the absence of a carboxyterminal amidation in the natural peptide, in agreement with its lesser hydrophobicity. In a recent study from our laboratory we isolated the naturally occurring GLP-1 from pig ileal mucosa. By amino acid sequencing on an Applied Biosystems gas phase sequenator we found that pig GLP-1 was identical with GLP-1 (7-36) (proglucagon 78-107), but the question of amidation remained unresolved [3]. By HPLC of synthetic GLP-2 and immunoreactive GLP-2 from the ileum using a $45-54 \%$ ethanol gradient elution, the two eluted well separated. This is in accordance with data from Heinrich et al. [2] who suggested that the first reported GLP-2 sequence (according to which synthetic GLP-2 was produced by Peninsula) was incomplete; a C-terminal amino acid was lacking.

The plasma profiles obtained by gel chromatography show that the predominating glucagon-like peptide in the fasting state is a large peptide which is at least GLP-1 immunoreactive. After a meal however, a large proportion of GLP-1-immunoreactivity eluted at the position of synthetic GLP-1 (1-36)/GLP-1 (7-36) suggesting that the peptide released in response to a mixed meal corresponds to the intestinal GLP-1. Similar experiments concerning immunoreactive GLP-2 in plasma were unsuccessful due to insufficient sensitivity of the assay combined with the dilution inherent to the chromatographic techniques. However, we have earlier reported that GLP-2 immunoreactivity increases after a meal [4].

So far, little is known about the physiological role of the glucagon-like peptides. We found no effect of synthetic GLP-1 (1-36) or GLP-2 on the endocrine secretion from the isolated perfused pig pancreas. Ghiglione et al. [21] found no effect of synthetic GLP-1 (1-37) on plasma levels of glucose and insulin. Schmidt et al. [22] demonstrated slightly increased insulin release from rat islet cells after incubation with GLP-1 (1-36) amide in rather high concentrations, but found no effect of synthetic GLP-2 on rat islets. We recently found a very marked, insulinotrophic effect of GLP-1 (7-36) amide - which is the naturally occurring GLP-1 in pigs - on the isolated perfused pig pancreas at concentrations above $10^{-11} \mathrm{~mol} / 1$ [3]. Similar findings were subsequently reported by Mojsov et al. [23] who studied the effect of synthetic GLP-1 (7-37) on insulin secretion from the rat pancreas. As discussed above, the concentrations of GLP-1 and GLP-2 immunoreactivity in plasma increase after a meal, suggesting a biological role of the naturally occurring GLP-1 or GLP-2 immunoreactive peptides; for GLP-1 possibly in the regulation of insulin secretion. Further progress regarding the physiological role of these intesting peptides requires determination of their exact structure in man.

Acknowledgements. We gratefully acknowledge the technical assistance of Ms L. Rabenhoj. This study was supported by Danish Medical Research Council, Novos Fond, P Carl Petersens Fond, Lægeforeningens Forskningsfond and "Fonden af 17/12 1981".

\section{References}

1. Bell GI, Sanchez-Pescador R, Laybourn PJ, Najarian RC (1983) Exon duplication and divergence in the human preproglucagon gene. Nature 304: 369-371

2. Heintich G, Gros P, Habener JF (1984) Glucagon gene sequence four of six exons encode separate functional domains of rat preproglucagon. J Biol Chem 259: 14082-14088

3. Holst JJ, Ørskov C, Schwartz TW (1987) Truncated glucagonlike peptide-1, an insulin-releasing peptide from the distal gut. FEBS Lett 221: 169-174

4. Ørskov C, Holst JJ (1987) Radioimmunoassays for Glucagon-like peptides 1 and 2 (GLP-1 and GLP-2). Scand J Clin Lab Invest 47: $165-174$

5. Schaffalitzky de Muckadell OB, Fahrenkrug J (1976) Preparation of ${ }^{125}$ I-labelled synthetic porcine secretin for radioimmunoassay. Scand J Clin Lab Invest 36: 661-668

6. Holst JJ (1982) Evidence that enteroglucagon (II) is identical with the C-terminal sequence (residues 33-69) of glicentin. Biochem J 207: 381-388

7. Holst JJ (1983) Gut glucagon, enteroglucagon, gut glucagonlike immunoreactivity, glicentin-current status. Gastroenterol 84: $1602-1613$

8. Scatchard G (1949) The attractions of proteins for small molecules and ions. Ann NY Acad Sci 51: 660-669

9. Holst JJ, Aasted B (1974) Production and evaluation of glucagon antibodies for radioimmunoassay. Acta Endocrinol (Copenh) 77 : 715-724

10. Newgard CB, Holst $\mathbf{J} \mathbf{J}$ (1981) Heterogeneity of somatostatin like immunoreactivity in extracts of porcine, canine and human pancreas. Acta Endocrinol (Copenh) 89: 564-572

11. Holst JJ, Pedersen JH, Baldissera FGA, Stadil F (1983) Circulating glucagon after total pancreatectomy in man. Diabetologia 25 : 396-399 
12. Sternberger L (1974) Immunohistochemistry. Prentice Hall, Englewood Cliffs, NJ, pp 129-171

13. Baldissera FGA, Holst JJ (1984) Glucagon-related peptides in the human gastrointestinal mucosa. Diabetologia 26: 223-228

14. Varndell IM, Bishop AE, Sikri KL, Uttenthal LO, Bloom SR, Polak JM (1985) Localization of glucagon-like peptide (GLP) immunoreactants in human gut and pancreas using light and electron microscopic immunocytochemistry. J Histochem Cytochem 33: $1080-1086$

15. Ørskov C, Holst JJ, Knuhtsen S, Baldissera FGA, Seier Poulsen S, Nielsen OV (1986) Glucagon-like peptides GLP-1 and GLP-2, predicted products of the glucagon gene, are secreted separately from pig small intestine but not pancreas. Endocrinol 119: 1467-1475

16. Patzelt C, Schiltz E (1984) Conversion of proglucagon in pancreatic alpha cells: the major endproducts are glucagon and a single peptide, the major proglucagon fragment, that contains two glucagon-like sequences. Proc Natl Acad Sci (USA) 81: 5007-5011

17. Uttenthal LO, Ghiglione M, George SK, Bishop AE, Polak JM, Bloom SR (1985) Molecular forms of glucagon-like peptide-1 in human pancreas and glucagonomas. J Clin Endocrinol Metab 61: $472-479$

18. George SK, Uttenthal LO, Ghiglione M, Bloom SR (1985) Molecular forms of glucagon-like peptides in man. Febs Lett 192: 275-278

19. Buhl T, Baldissera FGA, Holst JJ, Kofod J, Nielsen OV, Thim L, Orskov C (1987) Glucagon-like peptide 2 (GLP-2) in the porcine and human intestinal mucosa. J Physiol 390: 254P (Abstract)
20. Mojsov S, Heinrich G, Wilson IB, Ravazzola M, Orci L, Habener JF (1986) Preproglucagon gene expression in pancreas and intestine diversifies at the level of post-translational processing. J Biol Chem: 11880-11889

21. Ghiglione M, Uttenthal LO, George SK, Bloom SR (1984) How glucagon-like is glucagon-like peptide 1? Diabetologia 27: 599600

22. Schmidt WE, Siegel EG, Creutzfeldt W (1985) Glucagon-like peptide- 1 but not glucagon-like peptide- 2 stimulates insulin release from isolated rat pancreatic islets. Diabetologia 28: 704-707

23. Mojsov S, Weir GC, Habener JF (1987) Insulinotropin: Glucagonlike peptide $1(7-37)$ co-encoded in the glucagon gene is a potent stimulator of insulin release in the perfused rat pancreas. J Clin Invest 79: 616-619

Received: 11 June 1987

and in revised form: 8 September 1987

Dr. Jens Juul Holst

Institute of Medical Physiology C

Panum Institute

University of Copenhagen

Blegdamsvej 3c

DK-2200 Copenhagen $\mathrm{N}$

Denmark 